\title{
LINKING GORPORATE SOCIAL RESPONSIBILITY WITH REPUTATION AND BRAND OF THE FIRM
}

\author{
Jintao Lu ${ }^{1 *}$, Licheng Ren $^{2}$, Yifan $\mathrm{He}^{3}$, Wenfang Lin ${ }^{4}$ and Justas Streimikis ${ }^{5}$ \\ ${ }^{1) 2}$ School of Economics and Management and Research Center for Corporate \\ Social Responsibility, Taiyuan University of Science and Technology, Taiyuan, \\ P.R.China \\ ${ }^{344)}$ School of Economics and Management, \\ Taiyuan University of Science and Technology, Taiyuan, P.R.China \\ ${ }^{5)}$ Division of Farms and Enterprises Economics, \\ Lithuanian Institute of Agrarian Economics, Vilnius, Lithuania
}

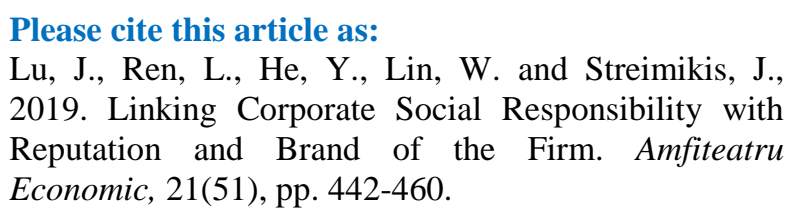

DOI: $10.24818 / \mathrm{EA} / 2019 / 51 / 442$

\section{Article History}

Received: 18 November 2018

Revised: 6 February 2019

Accepted: 30 March 2019

\begin{abstract}
There are no agreements among scientists in terms of relationships between Corporate Social Responsibility (CSR), Corporate Identity and Corporate Image (CI), Corporate Reputation (CR), and Corporate Brand (CB), and their mutual impacts as well the definition of these constructs cause a lot of scientific debates among scholars. The paper analyses the relationship between CSR, Corporate Image, Corporate Reputation and Corporate Brand and their outcomes linked to the financial and other benefits of the firm and society. The main studies that are dealing with this subject were analysed, and the theoretical model that is linking these constructs was developed. The proposed model can be used for carrying empirical studies in specific industries and branches of the economy in order to assess the main measures to increase Corporate Reputation and maximise its outcomes.
\end{abstract}

Keywords: corporate reputation, corporate brand, corporate image, corporate social responsibility

JEL Classification: Q01, Q35, Q51

\footnotetext{
* Corresponding author, Jintao Lu - lut2002@163.com
} 


\section{Introduction}

The importance of Corporate Social Responsibility (CSR) and Corporate Reputations (CR) is growing, as CSR is the main tool of the enterprise to increase sustainable development in developed and developing countries (Balmer and Geyser, 2003, 2006). Appropriate management of corporate reputation is especially important for firms that are having their main strengths and developing their competitive advantage and differentiation strategies based on such intangible assets as innovation, high intellectual capital and high organizational culture (Barney, 2001). The differentiation strategies are linked with resource-based view of developing strategy, providing how valuable and difficult it is to imitate such intangible assets like Corporate Reputation and Corporate Brands; therefore, these can provide for high profits and rapid growth of firms (Walker, 2010; Riera and Iborra, 2017).

Corporate Reputation (CR) has become even more important nowadays due to the corporate governance scandals linked to the dangerous products and services, corruption, involvement in politics etc. The recent worldwide corporate scandals highlighted the influence of irresponsible behaviour on damage for reputation and brand and bankruptcy of the well-known enterprises claiming themselves as responsible. The Corporate Hypocrisy, due to the irresponsible corporate policies, has attracted attention of many scholars in recent years as well (Janney and Gove, 2011; Armstrong and Kesten, 2013; Arli et al., 2017; Shim and Kim, 2017).

There are several theoretical and many empirical studies that are dealing with corporate reputation and company image, brands that provide for organizational success by allowing them to differentiate themselves from other organizations while remaining fully legitimate (Deephouse and Carter, 2005). In this field of research, the most popular issue that is being addressed is linked to marketing, branding and communications.

There is some important empirical proof of relationship between $\mathrm{CR}$ and Corporate Branding (CB) and financial performance (Roberts and Dowling, 2002). The CSR, corporate reporting requirements are as well driving the current interest in corporate reputation. Corporate image represents the public perception of the firm and is linked to the composite psychological impression of the firm's name. It is the public perception of the company unlike identity of the company. However, there is no clear agreement among scientists regarding the relationship between CSR, Corporate Image (CI) and Corporate Reputation (CR) and Corporate Brands (CB) and their outcomes. In addition, there are various definitions of $\mathrm{CR}, \mathrm{CI}$ and $\mathrm{CB}$ that are making development of theoretical frameworks even more difficult (Dowling, 2001; Crane et al., 2008; Wartik, 2012; Matera and Baena, 2012; Harvey, 2014).

Therefore, it is important to define the main drivers of corporate reputations and corporate brands and their outcomes and define the relationship between major constructs linked to the $\mathrm{CR}$ as there is a disagreement among practitioners and scholars in regard to the meaning of such concepts as Corporate Identity, Corporate Image, Corporate Reputation, Corporate Branding and their relationships and outcomes (MacMillan et al., 2005).

The aim of the paper is to develop a theoretical model that links corporate social responsibility, corporate image and corporate reputations and corporate branding to outcomes such as financial performance of the company etc. 
The paper is organized in the following way: the first section of the paper deals with literature review on the CSR and its various constituents and their linkages; second section deals with linkages between identity and image of the firm; third section provides linkages between corporate reputation and corporate brands; the fourth section provides a theoretical model for linking the main constructs, and the last section deals with outcomes of corporate reputation.

\section{Review of the scientific literature}

There are five main areas of current research on CSR: internal and external communication of CSR activities, implementation of CSR, stakeholder engagement, measurement of CSR activities and assessment of positive and negative economic outcomes of investing in the CSR activities (Lindgreen and Swaen, 2010).

One of the main topics in all these areas is the linkage between CSR positive outcomes and other important constructs such as Corporate Reputation (CR) and Corporate Image (CI) or Corporate Brands (CB). Though CSR activities are being considered as very positive for firms in general, some empirical studies indicated that the awareness of such activities, both internally with employees as well as externally with customers, is low and does not allow organizations to realize all the benefits of the CSR activities (Du et al., 2010).

As awareness and attribution of the CSR activities are central for the organizations to benefit from their investment, corporate communications are critical in this case. If a company has decided on its CSR strategy or identity, which is perceived externally via various forms of corporate communications, the main foundation of organizational identity is self- reference, which is related to the fact that a company or other organization can advance an autonomous self-definition which is not linked to how outsiders see or assess it. In addition, a self-reference provides idea that Corporate Identity supports organizations differentiation in the market (Dutton et al., 1994).

According to Whetten and MacKey (2002), Corporate Image (CI) can be defined as the official, projected autobiography of the organizational identity or/and the process of identification of the organization.

Whetton and Mackey (2002) provide the main ways in which organizations are able to construct, maintain and manage their identities in order to achieve desirable output on their reputations. However, according to Whetton and Mackey (2002), the management of CR is as well possible and quite justified as it creates greater opportunities for identification of organization among various stakeholders.

Therefore, the company's identity leads to communication, which leads to the CSR perception and CI, following CR and CB (Ashford and Mael, 1989; Hatch and Schultz, 2004).

Although, it is being widely accepted among scholars and practitioners that CSR initiatives have an impact on all stakeholders, Bhattacharya and Sen (2004) suggest that they have a particularly strong influence on customers. CR can moderate the effectiveness of CSR communication because stakeholders will already know the organization's reputation, and it is important to address this in its CSR communications. Yoon et al. (2006) pointed that organizations with good reputations can enhance their reputations through CSR communication, but organizations with poor reputations can potentially damage their reputation further through CSR communication because stakeholders do not believe in the authenticity of their CSR activities. 
Several studies (Coombs, 2007; Helms, 2007; Hillenbrand and Money, 2007; Yoon et al., 2006) identified how CR influences the processing of CSR information related to a specific organization. According to the Yoon et al. (2006), the bad reputation of the organization would have a negative effect on the CSR evaluation as well. If an organization has a bad reputation, the stakeholders will be suspicious whether there were ulterior motives for the organization to implement CSR. Therefore, Yoon et al. (2006) proved that in the case of good reputation, CSR will provide a lot of benefits for the firm (Sen and Bhattacharya, 2001); however, in the case of bad reputation, the effect of CSR implementation can be detrimental for the organization (Yoon et al., 2006). This mutual reinforcing relationship is very important for companies when shaping their differentiation strategies and investing in CSR and other intangible assets.

In addition, the awareness of stakeholders is very important when thinking about the impact of CSR communication on CR. Hillenbrand and Money (2007) argue that there are two alternative perspectives: first, CSR is a determinant of the CR, and second, CSR is a component of CR. The CSR overlaps with CR in terms of corporate behaviours and stakeholder perceptions. Hence, according to Hillenbrand and Money (2007), CSR and CR can be treated "as two sides of the same coin".

There is as well a disagreement among scientists on the concept of organizational culture, as some scholars highlighted the negative outcomes of multiple identities in the organizations (Hatch and Schultz, 2004). The fragmentation of organizational identities has negative implications for the $\mathrm{CR}$ of the firm.

According to Du et al. (2010), while CSR may be seen as an output of identity and communication, image, reputation and brand may be seen as an output of the CSR because there are multiple dimensions that create reputation, including CSR, CI, correspondence of actual companies' behaviour to CSR practices, reporting and information disclosure, communication effectiveness etc.

\section{Image and identity of the firm}

Scholars mainly agree that Corporate Image and Corporate Identity are the basic constituents of the Corporate Reputation. The identity is based on the perception of employees and managers (insiders), and image is based on the perception of external observers. In the end, Corporate Reputation is an important result of these perceptions (Fombrun and van Riel, 2003; Winsdor, 2013; Lorena, 2017; Maldonado-Guzman et al., 2017).

However, identity, image and reputation are still often used by some scholars as synonyms (Wartick, 2002). According to King and Whetten (2008), the Corporate Identity is an organization's exhibition of itself to its internal and external stakeholders. It is the main tool by which the company differentiates itself from all other enterprises and competitors. This view is similar to Fombrun and Shanley (1990) approach in defining Corporate Identity: the set of values and principles that the employees or internal stakeholders associate with their firm.

Therefore, most scholars understand Corporate identity as how employees ('internal stakeholders') understand their organization (Dutton and Dukerich, 1991; Bromley, 2000; 2002; Albert and Whetten, 1985). For internal stakeholders, this understanding is linked to what is the most important, central, and characteristic about their firm. 
Davies and Chun (2002) argued that there is a hierarchy with it being preferable to hold a superior identity than image because an organization's success should be driven inward rather than outward.

It is necessary to stress the strategic importance of the identity of the firm. The companies, which mainly direct their efforts and strategies to image building and management without previously forging a strong identity will only perform at secondary and short-term level (Aksak et al., 2016).

Most of the scholars understand Corporate Image as how external stakeholders understand their organization (Pruzan, 2001; Harvey, 2014).

However, there are many definitions of Corporate Image, which can be found in the scientific literature. The main definitions of corporate image are summarized and presented in Table no. 1.

Table no. 1: Corporate Image: Definitions and scope of different authors

\begin{tabular}{|c|c|}
\hline Authors & Definition \\
\hline Harvey, 2014 & $\begin{array}{l}\text { The impression of an organization of what it wants particular external } \\
\text { stakeholders to think is the most distinctive. }\end{array}$ \\
\hline $\begin{array}{l}\text { Mackelo and } \\
\text { Druteikiene, } \\
2010\end{array}$ & $\begin{array}{l}\text { Ideas and feelings linked to enterprise by individuals or groups, which } \\
\text { are affected by material and immaterial organizational elements, } \\
\text { communication and value systems. }\end{array}$ \\
\hline Balmer, 2010 & $\begin{array}{l}\text { It is based on the perception of other concepts such reputation, } \\
\text { cognition, attitude, credibility, belief etc. }\end{array}$ \\
\hline $\begin{array}{l}\text { Highhouse } \\
\text { et al., } 2009\end{array}$ & $\begin{array}{l}\text { What outsiders think about the organizations or what internal } \\
\text { stakeholder project about the organization to influence the outsiders. }\end{array}$ \\
\hline Van Riel, 2007 & Stakeholders' interpretations about the company. \\
\hline $\begin{array}{l}\text { Brown } \\
\text { et al., } 2005\end{array}$ & $\begin{array}{l}\text { Intended image: mental association of the organization that leaders want } \\
\text { important audience to hold. } \\
\text { Constructed image: mental association of the organization that the } \\
\text { organization's members think the outsiders hold about the organization. }\end{array}$ \\
\hline $\begin{array}{l}\text { Fombrun } \\
\text { and Riel, } 2003\end{array}$ & The organizational perception of external stakeholders. \\
\hline $\begin{array}{l}\text { Whetten and } \\
\text { Mackey, } 2002\end{array}$ & $\begin{array}{l}\text { What employees believe outsiders think about their organization; } \\
\text { what outsiders think about the organization; what employees signal to } \\
\text { outsiders, which influences how they think about the organization. }\end{array}$ \\
\hline Bromley, 2001 & $\begin{array}{l}\text { The collective state of mind that shapes organizations' } \\
\text { communications efforts to represent itself in public. }\end{array}$ \\
\hline Pruzan, 2001 & The perception of company from external observers. \\
\hline $\begin{array}{l}\text { Dutton and } \\
\text { Dukerich, } 1991\end{array}$ & Corporate image is how stakeholders think about the organization. \\
\hline
\end{tabular}

As one can see from the definitions provided in Table no. 1, most scholars emphasize the idea of perception of the organization by the external stakeholders in Corporate Image.

According to Bromley (2001), Corporate Image can be defined as the internal collective state of mind that shapes organization's communications efforts to represent itself to the public. However, according to Whetten and Mackey (2002), the Corporate Image is what 
organizational agents want their external stakeholders to appreciate as the most important, central, and characteristic about their company. In this case, the CI is mainly linked to the idea of desirable impressions by internal stakeholders that the external stakeholders should have about their company (Whetten and Mackey, 2002).

According to Whetten and Mackey (2002), there are three different understandings of corporate image: first, what employees believe outsiders think about their organization; second, what outsiders think about an organization; third, what employees signal to the outsiders, which in turn influences how they think about the organization.

Dutton and Dukerich (1991) have a quite similar understanding of Corporate Image like Whetten and Mackey (2002), or as how members of an organization think others see the organization. Highhouse et al. (2009) argue that it is more useful to think about the organizations having an 'image for' or an 'image as' something specific rather than a broad general image. An oil and gas company, for example, might have an excellent image for shareholder return, but a poor image for employee safety. Equally, a management consultancy company might have a strong image for attracting talented employees, but a weak image for retaining and developing existing employees.

Balmer (2010) highlighted that Corporate Image has an impact on the public behaviour. In his study, Balmer (2010) proved that Corporate Image centres around the substitutable perception of other concepts such as perception, attitude, credibility and belief; however, the Corporate Identity is linked to the specific organizational behaviours that are driving companies apart from other companies and organizations. Corporate Identity is more related to the organizational appearance and various organizational activities, including corporate ownership and structure, products, innovativeness, corporate management etc. (Balmer, 2010).

There is no clear understanding and agreement between scholars in terms of Corporate Image and Corporate Reputation differences and relationships. Some scholars separate Corporate Image and Corporate Reputation, whereas others see the two as identical. Gotsi and Wilson (2001) make the distinction between the two major schools of thought: the analogous school of thought treats Corporate Reputation and Corporate Image as synonymous, and the differentiated school of thought considers these terms related but different. According to Gotsi and Wilson (2001), the differentiated school of thought has received stronger academic support up until now, and there is some common understanding among most of the scholars dealing with this subject that Corporate Image and Corporate Reputation are different concepts but have a bilateral relationship.

Wei (2002) highlighted that Corporate Reputation should not subsume Corporate Image, but rather the image should subsume reputation. Wei (2002) provides an explanation that if Corporate Reputation flows from persuasion, it ought to be subsumed under 'image,' not the other way around.

However, it is necessary to point again to the bilateral relationship between these constructs. Corporate reputation has an impact on the Corporate Image. Corporate Image and Corporate Identity provide for Corporate Reputation.

Corporate Reputation is linked to Corporate Brand, and these relationships as well need to be analysed in more detail in order to reveal their bilateral relationship. 


\section{Corporate Reputation and Corporate Brand of the firm}

Corporate Reputation can be considered as an important intangible asset of an organization that is stemming from the firm's past positive interactions with stakeholders. According to the most of scholars (Gray and Balmer, 1998; Williams and Barrett, 2000; Barney, 2001; Argenti and Druckenmiller, 2004; McMillan et al., 2005; Barnett et al., 2006), Corporate Reputation provides the assessment of unique qualities of organization and reduces ambiguity about its performance and product quality. Good corporate reputation provides important benefits to the organization by enhancing advantageous public opinion and a friendly business environment (Fombrun et al., 2000). The good Corporate Reputation is the main driver of consumers' trusts of the brand, which is being treated by the scholars in different ways.

The main reputation components, created by the Reputation Institute (2013) for companies ranking based on Corporate Reputation, derived from Fombrun's Reputation Quotient (RQ). This ranking is based on seven important dimensions of Corporate Reputation: Financial performance, Quality of products and services, Innovation, Workplace quality, Governance and transparency, Citizenship, Leadership.

According to Barron and Rolfe (2011), three main dimensions of Corporate Reputation ranking are linked to the main CSR areas: the quality of the workplace, good governance and transparency, citizenship.

The high workplace quality indicates why the firm is an attractive place to work and how company handles its relationship with employees. In terms of better quality of the workplace, it is important to ensure pleasant and rewarding workplace and a way organization would be capable to recognize the capabilities of its employee. The good governance and transparency is linked to ethical and transparent management of the company. The Citizenship addresses such issue as being a good corporate citizen as important for the organization. Such company protects the environment and takes care of social problems in the society. These 3 main dimensions together represent more than the $40 \%$ of organizations' reputation (Barron and Rolfe, 2011). The good Corporate Reputation ensures that the customers trust and support the brand of the company. Therefore, all these key dimensions, including good quality of products/services, must be controlled by the organizations, because in the case of failure to address them adequately, these dimensions may cause major damage to the Corporate Reputation of the company (Griffin, 2010).

The literature on reputation suggests that it has a number of important characteristics: it is the perception and evaluation, the aggregation of attributes, a judgment that is relative to competitors, either positive or negative, and based on past performance and future projections (Walker, 2010). According to Harvey (2014), reputation is a judgment for something, with someone, it is analysed who is judging it and where and over what period of time. CR incorporates multiple dimensions and is a reflected judgment; other constructs such as CSR, Corporate Identity, Corporate Image are a central antecedent of Corporate reputation.

Therefore, the basic components of $\mathrm{CR}$ are identity and image of the firm. According to Brown et al. (2005), CR is mental associations about the firm that outsiders held. Corporate Reputation can be addressed as an integrative perspective of a firm from various stakeholders. The Corporate Image is the perception of a company from external observers, whereas Corporate Identity is linked to the firm employee perception about their organization. 
Corporate Reputation is formed by the public perceptions of various assets and characteristics of the company and can be defined in terms of firms' relationship with various stakeholders inside and outside the firm.

According to Fombrun and Riel (2003), the CR is a firm's relative standing both internally with employees and externally with its stakeholders.

The recent definition of CR concept stems from the idea of cognitive representation of the firms' activities that indicate the organization's capabilities to provide valued outcomes to its various stakeholders (Fombrun et al., 2000).

Some scholars sustain that the term "image" evolved into reputation mostly because of the polysomic and negative connotations of the former (Lievens et al., 2007; Rindova et al., 2010). If considered from a reception-oriented approach, the two concepts can be defined as mental associations in the mind of perceiving publics; thus, their perceptions, even if resulting from organizational efforts, belong to the receptors; thus, they are less directly controllable for the organization (Caudron, 1997; Kitchin, 2003; Kärreman and Rylander, 2008; Lai et al., 2010).

It can be stressed that Corporate Image and reputation are tools to exert influence on public and stakeholders, while as a reception construct, they are both associations in the mind of the public and stakeholders. Image is more a product of the communicative efforts of the organization, while reputation results from organizational behaviour and its assessment by the external stakeholders.

In Table no. 2, the definitions of corporate reputation are summarized and presented.

Table no. 2: Definitions of corporate reputation by different authors

\begin{tabular}{|c|c|}
\hline Authors & $\begin{array}{l}\text { Definitions and scope } \\
\end{array}$ \\
\hline Harvey, 2014 & $\begin{array}{l}\text { A judgment for something, with someone, in some place and over time. } \\
\text { It is analysed who is judging it and where and over what period of time. }\end{array}$ \\
\hline $\begin{array}{l}\text { Ponzii et al., } \\
2011\end{array}$ & $\begin{array}{l}\text { Beliefs about firm past and future activities that affect stakeholder } \\
\text { interaction with them. }\end{array}$ \\
\hline $\begin{array}{l}\text { Lange et al., } \\
2011\end{array}$ & $\begin{array}{l}\text { Generalized awareness, visibility; perceived predictability of } \\
\text { organizational outcomes; judgement of the overall organization as good, } \\
\text { attractive, etc. }\end{array}$ \\
\hline $\begin{array}{l}\text { Barnet et al., } \\
2006\end{array}$ & Is based on awareness, assessment, asset. \\
\hline $\begin{array}{l}\text { Brown et al., } \\
2005\end{array}$ & Mental associations about the company that outsiders have. \\
\hline $\begin{array}{l}\text { Argenti and } \\
\text { Druckenmiller, } \\
2004\end{array}$ & $\begin{array}{l}\text { Collective representation of multiple images about organization that are } \\
\text { created over time and based on a company's identity programs, its } \\
\text { performance and how stakeholders perceive the firm's behaviour. }\end{array}$ \\
\hline $\begin{array}{l}\text { Gotsi and } \\
\text { Wilson, } 2001\end{array}$ & $\begin{array}{l}\text { The global evaluation of different assessments, judgements or images } \\
\text { that public has about an organization. }\end{array}$ \\
\hline $\begin{array}{l}\text { Fombrun et } \\
\text { al., } 2000\end{array}$ & $\begin{array}{l}\text { A cognitive perception of the firm's activities that create company's } \\
\text { capabilities to deliver valued outcomes to various stakeholders. }\end{array}$ \\
\hline $\begin{array}{l}\text { Fombrun and } \\
\text { Riel, } 2003\end{array}$ & $\begin{array}{l}\text { The relative position of the firm that is internal in term of employees and } \\
\text { external in terms of other stakeholders. }\end{array}$ \\
\hline
\end{tabular}


Based on the definitions that are presented in Table no. 2, one can conclude that the CI and $\mathrm{CR}$ are reception constructs related to the reception side of the institutional communication process. Therefore, the communication relates to corporate identity in two ways: first, it is necessary to define how to fulfil organization's mission and make the organization's mission known by all the stakeholders. These two issues of corporate identity will significantly influence the perceptions or CI and evaluations by public of the company or CR. All these have an impact on brands and positive outcomes of the investments in CSR.

In addition, CR has to deal with assessment or evaluation of the CI that has been formed in the minds of its stakeholders Thus, proactive and operative institutional communication programmes are vital to increase the $\mathrm{CR}$ by communicating institutional successes and strengths and maintaining positive relations with internal and external stakeholders.

The Corporate Brand (CB) is focused on the customer or client and emphasizes what the product, service or organization has promised them as well as what that promise means to them (Ettenson and Knowles, 2008). A brand is the name, logo or design of an organization that is used to signal to customers to differentiate itself from its competitors. Typically, company names and logos will be used alongside other forms of corporate communication, such as advertising, which aims to reinforce the brand (Fetscherin, 2012).

There are some debates about whether the CB is solely a focus on the customer. Ettenson and Knowles (2008) stated that the CB is linked to customers and emphasize the product or service which an organization has promised to its customers. This is distinct from a CR which focuses on the organization's credibility and respect among multiple constituencies. In both cases, strategic communication is critical for the organizations to display symbols as well as signal quality products and services in order to project them in the most positive way.

\section{The linkages of CSR to identity, image, reputation and brand}

There have been different claims about the relationship of CSR to identity, CI, CR and CB. Most scholars agree that CSR reporting has a positive impact on the Corporate Reputation and financial performance of the company and provides good possibilities to attract foreign investors and greater consumer's satisfaction and loyalty and employee commitment and loyalty (Barnet, 2007; Stanaland et al., 2011; Matten and Moon, 2008; Melo and Galan, 2011).

Comparing with other constructs linked to the CSR, there is little work on the relationship between corporate identity and CSR. This is likely because scholars usually view CSR as one of the important dimensions of an organization's identity. However, it is necessary to investigate more deeply the relationship between these two constructs; it is clear that there is a reinforcing relationship between them.

Many studies have analysed the impact of CSR on Corporate Image and Corporate Reputation of the organization (Brown and Dacin, 1997; Sen, Bhattacharya and Korschun, 2006). In addition, scholars have investigated the perceived importance of CSR for various stakeholders and in driving purchase intentions (Chua and Lin, 2013) and building strong Corporate Brand (Ragas and Roberts, 2009; Werder, 2008).

Dutton et al. (1994) proved that images of organizations shape how stakeholders identify themselves with the organization. Davies et al. (2001) suggest that CR is the sum of image and identity, which Wartick (2002) argues due to the problem of aggregating perceptions about the company across the stakeholder groups. Walker (2010) agreed with Davies et al. 
(2001) and other scholars and insisted that reputation is related to the judgment of internal and external stakeholders about the company and consists of corporate identity and corporate image.

Gray and Balmer (1998) added that the organization's identity is connected to its image and reputation by its communication. In particular, all kinds of formal and informal information sources are disseminated to different stakeholders by shaping their impressions and judgments about companies. Therefore, many scholars highlighted that visibility and familiarity are important drivers of good corporate reputation (Apéria, Brønn and Schultz, 2004). Therefore, companies need publicity through the media in order to build good corporate reputation. However, there are risks that are associated with media publicity, as the media decides how to present information, i.e., negatively or positively (Apéria, Brønn and Schultz, 2004). This gives media a powerful position in corporate reputation building process as it is an important channel to reach stakeholders and influence how the messages will be formed and later perceived. Some scholars pointed out that publicity can lead to great opportunities for organizations to create favourable relationships with their stakeholders, but as mentioned above, publicity can become devastating if the attention is perceived negatively.

Caudron (1997) argues that reputation matters more than image, because it is merely one input into the dimension, and image is a product of identity and reputation rather than vice-versa.

The conducted literature review provided that CSR, CR and CB are positively correlated. Husted and Allen (2007) proved that by building stakeholder's and customer awareness of products, CSR may have a positive impact on the Corporate Reputation and together may create a stronger brand for firms' customers.

Argenti and Druckenmiller (2004) provided the importance of Corporate Brands as organization could define and communicate its identity and brand, but not its image and reputation, which are not under firm's control and are shaped by internal and external stakeholders. Since a brand creates expectations among customers, organizations that continue to meet these expectations will create a positive image over time, which will enhance its reputation. Hence, a strong brand is an important precursor to a positive image and reputation.

Husted and Allen (2007) provided in their study that good Corporate reputation and strong Corporate brand have an important impact on the value creation in the company, and these are intangible assets, which are not easy to replicate. Corporate Reputation and Corporate Brand are the main sources of competitive advantage of companies in the markets where product and service differentiation is difficult for all the market players. Melo and Galan (2011) proved in their study that the competitive advantage of the company could be strengthened through the CSR activities.

According to Castaldo et al. (2009) and Park et al. (2014), the CSR practices can drive customer's choice of products or services as ethical CSR practices usually create a customer's strong belief that the company follows high ethical standards and takes society's wellbeing seriously. This, in turn, has positive impacts on the consumer assessment of Corporate Reputation and provides the establishment of strong Corporate Brands. Lamberti and Lettieri (2009) proved that if stakeholders become aware of firm's ethical behaviour, they trust that these companies will ensure appropriate quality standards in order to maintain their good Corporate Reputation. 
According to Melo and Garrido (2012), CSR is a very complex construct, and all its dimensions have specific impact on the Corporate Reputation.

Perez (2015) highlighted that the overall reputational impact of CSR is linked to a specific CSR dimension that is under consideration by the stakeholders. For example, a strong record of social performance will drive Corporate Reputation in relation to how these corporate activities fit with stakeholders' social concerns and values.

Another important issue in analysing CSR linkages with other constructs is the responsible behaviour of companies due to the recent corporate scandals and corporate hypocrisy. Unfortunately, there are some contradictions between CSR and the responsible behaviour of the firms.

Corporate hypocrisy may occur if organization's observable behaviour is different from its observable statements and commitments in terms of CSR. If stakeholders have internalized some important issues of organization's Corporate Identity, they may feel betrayed by the company and would like to keep a distance from it by seeking to secure their own sense of identity (Sen and Bhattacharya, 2001).

Kotchen and Moon (2012) showed that sometimes, CSR is used as a strategy to divert attention away from firms' unethical behaviour by using CSR to cover its socially irresponsible behaviour. Sometimes, CSR is used for "image washing" of companies that are seeking to enhance the reputation among stakeholders. This "image washing" has a significant negative impact on a company's performance by damaging its Corporate Image, Corporate Reputation and Corporate Brand and in certain cases, is the main reason of bankruptcy of the firm.

Kärreman and Rylander (2008) argued that regardless of the brand impact on internal or external stakeholders, in both situations, CSR activities, whether they are perceived positively or negatively, are strongly correlated with the organization's reputation and brand (Bhattacharya and Sen, 2004; Li, Sun and Li, 2018). Therefore, positive CSR and responsible behaviour of the company, which is well-communicated, promote good CR and strong CB, and good CR and strong CB promote positive outcomes of the CSR (Harvey, 2014).

In Figure no. 1, the conceptual model that is linking CSR with other constructs is presented.

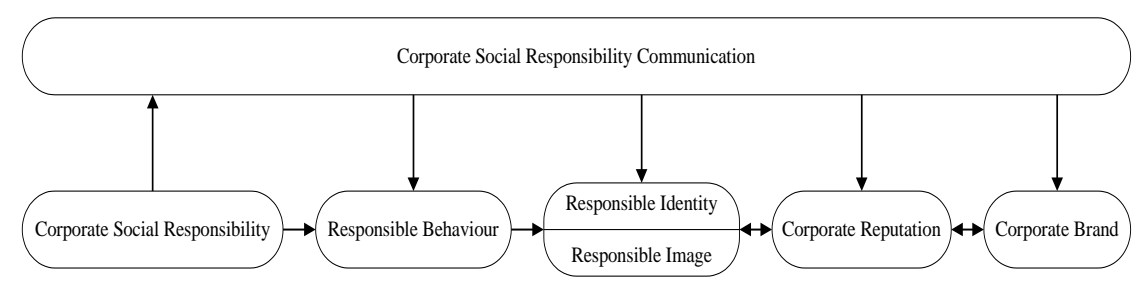

Figure no. 1: Conceptual model

As one can notice from the conceptual model that is linking CSR with other constructs, CSR has a positive impact on the Corporate Reputation and Corporate Brand through the chain of mutual and reinforcing impacts. Responsible behaviour and appropriate communication strategies that are targeting internal and external stakeholders are the main drivers of positive effect of the CSR on the Corporate Identity and Corporate Image, forming strong Corporate Reputation and strong Corporate Brands. As it was noted above, the strong Corporate Brands as well allow increasing the Corporate Reputation and has an 
impact on the Corporate Image. In addition, CSR is a part of the Corporate Identity and is implemented because of the Corporate Identity. The most important in this conceptual model is that all these constructs are linked and mutually reinforcing each other. Though the conceptual model indicates the top-down direction of mutual impact, the bottom-up direction is possible as well.

\section{Outcomes of the Corporate Reputation}

The relationships between Corporate Reputation, Corporate Brand and financial performance of the company can be indirect and influenced by various factors as the gap between Corporate Image and Corporate Identity, Corporate Hypocrisy, customer satisfaction and employee commitment and loyalty. All these interlinked factors can be either antecedents or consequences of Corporate Reputation, Corporate Brand and may lead to better financial results and sustainable development of the company in the long term.

A strong Corporate Brand and a good Corporate Reputation stimulate a purchase of customers as it provides for simplified decision-making processes. In the marketing literature, there is a clear link between reputation and satisfaction, which is perceived as quality by the customers. A good reputation for high quality means more customers, fewer dissatisfied customers and increases of profitability. In addition, the satisfaction of customers and their loyalty positively influence Corporate Reputation and create Strong Brand (Anderson and Sullivan, 1993). Therefore, Corporate reputation can be treated as microeconomic result of customer's satisfaction with the products and services of the firm (Anderson and Fornell 1994).

Andreassen (1994) proved in his study that Corporate Reputation has a positive impact on the customers' satisfaction and loyalty. However, there is no statistically validated relationship between satisfaction and loyalty. Andreassen and Lindestad (1998) as well proved a strong relationship between customers' satisfaction and Corporate Reputation. Though it is a popular way of thinking that customers' satisfaction is the main link, which relates company's reputation to profitability, the relationships between reputation, satisfaction and financial performance are under-researched. In particular, there is a lack of studies that are investigating the relationship between customer satisfaction and the Corporate Image.

In addition, good Corporate Reputation has positive impacts in terms of lower employee turnover (Winkleman, 1999); though the relationship between employee retention measures and their job satisfaction and low turnover is not straightforward.

According to Michaels and Spector (1982), there is link between job satisfaction and employee turnover as the length of employment indicates employee loyalty to the firm and great commitment to the firm's identity (Loveman, 1998). However, scholars proved that there are many important variables that have an impact on employee turnover, as employees often leave the firm due to the promotion that was obtained elsewhere or because their spouse changed the workplace, and they are following spouse to the other locations (Reichheld, 1996).

Based on Sergeant and Frenkel (2000) study, the interactions between customer and employees as well have a positive influence on customer satisfaction and enhancement of a company's reputation and strengths of the Corporate Brands. It is necessary to stress that 
loyal and motivated employees usually stay with the company for a longer period and know the customers of the firm better. This, in turn, provides for the better services of the company for its customers and the increase of the customer satisfaction with products and services of the firm and serves as a mediating factor for improving Corporate Reputation (Reichheld, 1996).

In addition, the satisfied customers are pleased with the value that they receive from the company, and their satisfaction has an impact on the pride and satisfaction of the employees. Therefore, customers and employee satisfaction are mutually reinforcing and having clear interlinkages with Corporate Reputation. The highest customer retention leads to employee retention because happy employees give better services to the customer to increase the customer's satisfaction (Heskett et al., 1994).

However, if the impact of CR and CB is linked to the CSR activities, the benefit of CR and $\mathrm{CB}$ can be even greater as it provides additional benefits to society like pursuing sustainable development goals all over the world.

\section{Conclusions}

Though there were several attempts to understand the relationships between CSR, Corporate Identity, Corporate Image, Corporate Reputation and Corporate Brand; however, there are no comprehensive analysis that was conducted to assess how one construct that is linked to the CSR affects another construct, for example, how CSR effect reputation or image and vice-verse, how reputation influence CSR.

However, it is necessary to understand how these constructs are interlinked in order to develop effective strategies of differentiation and achieve competitive advantage. This would allow companies to make decisions on investment in intangible assets such as CSR initiatives.

The importance of defining and connecting CSR to other constructs such as Corporate Identity, Corporate Image and Corporate Reputation and Corporate Branding is as well very important in defining communication strategies, selecting communication channels of internal and external communication in order to ensure that the stakeholders would perceive its signals.

The conceptual model that is linking CSR with other constructs shows a positive impact of CSR on Corporate Reputation and Corporate Brand through the chain of mutual and reinforcing impacts. Responsible behaviour and appropriate communication strategies that are targeting internal and external stakeholders are necessary to ensure a positive effect of CSR on Corporate Identity and Corporate Image by forming strong Corporate Reputation and strong Corporate Brands.

The strong Corporate Brands have a positive impact on the Corporate Reputation as well as on the Corporate Image. In addition, CSR is a part of the Corporate Identity, and through this construct, Corporate Reputation is being created. The most important in developing conceptual model is that all these constructs are linked and mutually reinforcing each other as top-down and bottom-up directions are viable in the developed conceptual model.

The developed conceptual model establishes the relationship between major CSR constructs, and further empirical research is needed to test these links and define the best ways for organizations to manage these different constructs and how much weight stakeholders place on the specific construct. 


\section{Acknowledgement}

This work was supported by the Program for the Philosophy and Social Sciences Research of Higher Learning Institutions of Shanxi (PSSR: 2017336) and the Doctoral Scientific Research Foundation of Taiyuan University of Science and Technology (No. W20182014).

\section{References}

Aksak, E.O., Ferguson, M.A. and Duman, S.A., 2016. Corporate social responsibility and CSR fit as predictors of corporate reputation: A global perspective. Public Relations Review, 42(1), pp. 79-81.

Albert, S. and Whetten, D.A., 1985. Organizational identity. In: L.L. Cummings and B.M. Staw, eds. 1985. Research in Organizational Behavior. Greenwich, CT: JAI Press, pp. 263-295.

Armstrong, J.S. and Kesten, C.G., 2013. Effects of corporate social responsibility and irresponsibility policies. Journal of Business Research, 66, pp. 1922-1927.

Anderson, E.W. and Sullivan, M.W., 1993. The antecedents and consequences of customer satisfaction for firms. Marketing Science, 12(2), pp. 125-143.

Andreassen, T.W., 1994. Satisfaction, loyalty and reputation as indicators of customer orientation in the public sector. Journal of Public Sector Management, 7(2), pp. 16-34.

Andreassen, T.W. and Lindestad, B., 1998. The effect of corporate image in the formation of customer loyalty. Journal of Service Research, 1(1), pp. 82-92.

Apéria, T., Brønn, P.S. and Schultz, M., 2004. A reputation analysis of the most visible companies in the Scandinavian countries. Corporate Reputation Review, 7(3), pp. 218-230.

Arli, D., Grace, A., Palmer, J. and Pham, C., 2017. Investigating the direct and indirect effects of corporate hypocrisy and perceived corporate reputation on consumers' attitudes toward the company. Journal of Retailing and Consumer Services, 37, pp. 139-145.

Argenti, P.A. and Druckenmiller, B., 2004. Reputation and the corporate brand. Corporate Reputation Review, 6(4), pp. 368-374.

Ashforth, B.E. and Mael, F., 1989. Social identity theory and the organization. Academy of Management Review, 14(1), pp. 20-39

Balmer, J., 2001. Corporate identity, corporate branding and corporate marketing: Seeing through the fog. European Journal of Marketing, 35(3/4), pp. 248-291.

Balmer, J.T. and Greyser, S.A., 2003. Revealing the Corporation: Perspectives on Identity, Image, Reputation, Corporate Branding and Corporate-Level Marketing. London: Routledge.

Balmer, J. and Greyser, S., 2006. Corporate marketing - Integrating corporate identity, corporate branding, corporate communications, corporate image and corporate reputation. European Journal of Marketing, 40(7/8), pp. 730-741.

Barney, J., 2001. Is the resource-based 'view' a useful perspective for strategic management research. Academy of Management Review, 26(1), pp. 22-40.

Barnett, M.L., Jermier, J.M. and Lafferty, B.A., 2006. Corporate reputation: The definitional landscape. Corporate Reputation Review, 9(1), pp. 26-38. 
Barnett, M.L., 2007. Stakeholder influence capacity and the variability of financial returns to corporate social responsibility. Academy of Management Review, 32(3), pp. 794-816.

Barron, D. and Rolfe, M., 2011. Measuring Reputation: Corporate Appeal, Political Influence and Regulation. Oxford University. [LEF?

Bhattacharya, C.B. and Sen, S., 2004. Doing better at doing good: When, why, and how consumers respond to corporate social initiatives. California Management Review, 47(1), pp. 9-24.

Bromley, D.B., 2000. Psychological aspects of corporate identity, image and reputation. Corporate Reputation Review, 3(3), pp. 240-252.

Bromley, D.B., 2002. Comparing corporate reputations: League tables, quotients, benchmarks, or case studies. Corporate Reputation Review, 5(1), pp. 35-50.

Brown, T.J., Dacin, P.A., Pratt, M.G. and Whetten, D.A., 2005. Identity, image, and reputation: An interdisciplinary framework and suggested terminology. In: s.n., The Academy of Marketing Science Conference. 2005. Tampa, FL, U.S.A. s.l:s.n.

Castaldo, S., Perrini, F., Misani, N. and Tencati, A., 2009. The missing link between corporate social responsibility and consumer trust: The case of fair trade products. Journal of Business Ethics, 84(1), pp. 1-15.

Caudron, S., 1997. Forget image: It's our reputation that matters. Industry Week, 246, pp. 13-16.

Chua, S.C. and Lin, J.S., 2013. Consumers' perception of corporate social responsibility in the United States and China: A study of female cosmetics consumers. International Journal of Strategic Communication, 7(1), pp. 43-64.

Coombs, W.T., 2007. Protecting organization reputation during a crisis: The development and application of situational crisis communication theory. Department of Communication Studies, Eastern Illinois University, Charleston, IL, USA. Corporate Reputation Review, 10(3), pp. 163-176.

Crane, A., McWilliams, A., Matten, D., Moon, J. and Siegel, D.S. eds., 2008. The Oxford Handbook of Corporate Social Responsibility. Oxford: Oxford University Press.

Davies, G. and Chun, R., 2002. Gaps between the internal and external perceptions of the corporate brand. Corporate Reputation Review, 5(2-3), pp. 144-158.

Deephouse, D.L. and Carter, S.M., 2005. An examination of differences between organizational legitimacy and organizational reputation. Journal of Management Studies, 42(2), pp. 329-360.

Dowling, G.R., 2001. Creating Corporate Reputations: Identity, Image and Performance. New York: Oxford University Press.

Du, S., Bhattacharya, C.B. and Sen, S., 2010. Maximizing business returns to corporate social responsibility (CSR): The role of CSR communication. International Journal of Management Review, 12(1), pp. 8-19.

Dutton, J.E., Dukerich, J.M. and Harquail, C.V., 1994. Organizational images and member identification. Administrative Science Quarterly, 39(2), pp. 239-263.

Ettenson, R. and Knowles, J., 2008. Don't confuse reputation with brand. MIT Sloan Management Review, 49(2), pp. 19-21. 
Fetscherin, M. and Usunier, J.C., 2012. Corporate branding: An interdisciplinary literature review. European Journal of Marketing, 46(5), pp. 733-753.

Fombrun, C.J. and Shanley, M., 1990. What's in a name? Reputation building and corporate strategy. Academy of Management Journal, 33(2), pp. 233-258.

Fombrun, C.J., Gardberg, N. and Barnett, M.L., 2000. Opportunity platforms and safety nets: Corporate citizenship and reputational risk. Business and Society Review, 105(1), pp. 85-106.

Fombrun, C.J. and Van Riel, C.B.M. 2003. Fame \& Fortune: How Successful Companies Build Winning Reputations. Upper Saddle River, NJ: Financial Times/Prentice Hall.

Gotsi, M., Wilson, A.M. 2001. Corporate reputation: Seeking a definition. Corporate Communications: An International Journal, 6(1), pp. 24-30.

Gray, E.R. and Balmer, J.M.T., 1998. Managing corporate image and corporate reputation. Long Range Planning, 31(5), pp. 695-702.

Griffin, A., 2010. The long-term value of reputation to business. Regester Larkin Reputation Strategy and Management. [online] Available at: <http://www.regesterlarkin.com/uploads/the_longter m_value_ofreputation_to_business.pdf> [Accessed 14 February 2019].

Harvey, W.S., 2014. Defining and connecting CSR, reputation, image, identity, brand, legitimacy, status and diversity. In: M. Karataş-Ozkan, K. Nicolopoulou and M.F. Özbilgin, eds. 2014. Corporate Social Responsibility and Human Resource Management. A Diversity Perspective. S.1.:s.n.

Hatch, M.J. and Schultz, M., 2004. Organizational Identity: A Reader. Oxford: Oxford University Press.

Helm, S., 2007. One reputation or many? Comparing stakeholders' perceptions of corporate reputation. Corporate Communications: An International Journal, 12(3), pp. 238-254.

Heskett, J.L., Jones, T.O., Loveman, G.W., Sasser, W.E.J. and Schlesinger, L.A., 1994. Putting the service profit chain to work. Harvard Business Review, 72, pp. 164-174.

Highhouse, S., Brooks, M.E. and Gregarus, G., 2009. An organizational impression management perspective on the formation of corporate reputations. Journal of Management, 35(6), pp. 1481-1493.

Hillenbrand, C. and Money, K., 2007. Corporate responsibility and corporate reputation: Two separate concepts or two sides of the same coin? Corporate Reputation Review, 10(4), pp. 261-277.

Husted, B.W. and Allen, D.B., 2007. Strategic corporate social responsibility and value creation among large firms. Lessons from the Spanish experience. Long Range Planning, 40, pp. 594-610.

Janney, J.J. and Gove, S., 2011. Reputation and corporate social responsibility aberrations, trends, and hypocrisy: Reactions to firm choices in the stock option backdating scandals. Journal of Management Studies, [e-journal] 48(7), pp.1562-1585. doi: 10.1111/j.14676486.2010.00984.x.

Kärreman, D. and Rylander, A., 2008. Managing meaning through branding - The case of a consulting firm. Organization Studies, 29(1), pp. 103-125. 
King, B.G. and Whetten, D.A., 2008. Rethinking the relationship between reputation and legitimacy: A social actor conceptualization. Corporate Reputation Review, 11(3), pp. 192-207.

Kitchin, T., 2003. Corporate social responsibility: A brand explanation. Journal of Brand Management, 10(4), pp. 312-326.

Kotchen, M. and Moon, J.J., 2011. Corporate social responsibility for irresponsibility. The B.E. Journal of Economic Analysis \& Policy [e-journal] 12(1), p. 55. doi: 10.1515/19351682.3308

Lai, C.S., Chiu, C.J., Yang, C.F. and Pai, D.C., 2010. The effects of corporate social responsibility on brand performance: The mediating effect of industrial brand equity and corporate reputation. Journal of Business Ethics, 95(3), pp. 457-469.

Lamberti, L. and Lettieri, E., 2009. CSR practices and corporate strategy: Evidence from a longitudinal case study. Journal of Business Ethics, 87(2), pp. 153-168.

Lange, D., Lee, P.M. and Dai, Y., 2011. Organizational reputation: A review. Journal of Management, 37(1), pp. 153-184.

Li, J., Sun, X. and Li, G., 2018. Relationships among Green Brand, Brand Equity and Firm Performance: Empirical Evidence from China, Transformations in Business \& Economics, 17, 3(45), pp. 221-236.

Lievens, F., Van Hoye, G. and Anseel, F., 2007. Organizational identity and employer image: Towards a unifying framework. British Journal of Management, 18 (SI), pp. S45-S59.

Lindgreen, A. and Swaen, V., 2010. Corporate social responsibility. International Journal of Management Reviews, 12(1), pp. 1-7.

Lorena, A., 2018. The relation between corporate social responsibility and bank reputation: A review and roadmap. European Journal of Economics and Business Studies, 4(2), pp. 7-21.

Loveman, G.W., 1998. Employee satisfaction, customer loyalty and financial performance: An empirical examination of the service profit chain in retail banking. Journal of Service Research, 1(1), pp. 18-31.

Maldonado-Guzman, G., Pinzón-Castro, S.Y. and Leana-Morales, C., 2017. Corporate social responsibility, brand image and firm reputation in Mexican small business. Journal of Management and Sustainability, 7(3), pp. 38-47.

Mackelo, O. and Drūteikienè, G., 2010. The image of a higher education institution, its structure and hierarchical level: The case of the Vilnius University Faculty of Economics. Ekonomika, 89(3), pp. 105-121.

MacMillan, K., Money, K., Downing, S. and Hillenbrand, C., 2005. Reputations in relationships: Measuring experiences, emotions and behaviours. Corporate Reputation Review, 8(3), pp. 214-232.

Mattera, M. and Baena, V., 2012. Corporate reputation and its social responsibility: A comprehensive vision. Cuadernos de Estudios Empresariales, [e-journal] 22, pp. 129-149 http://dx.doi.org/10.5209/rev_CESE.2012.v22.44648.

Matten, D. and Moon, J., 2008. „Implicit” and „explicit” CSR: A conceptual framework for a comparative understanding of corporate social responsibility. Academy of Management Review, 33(2), pp. 404-424. 
Melo, T. and Galan, J.I., 2011. Effects of corporate social responsibility on brand value. Journal of Brand Management, 18(6), pp. 423-437.

Melo, T. and Garrido, A., 2012. Corporate reputation: A combination of social responsibility and industry. Corporate Social Responsibility and Environmental Management, 19(1), pp. 11-31. iL

Pérez, A., 2015. Corporate reputation and CSR reporting to stakeholders. Corporate Communications: An International Journal, 20(1), pp. 11-29.

Michaels, C.E. and Spector, P.E., 1982. Causes of employee turnover: A test of the Mobley, Griffeth, Hand and Meglino model. Journal of Applied Psychology, 67(1), pp. 53-59.

Park, J., Lee, H. and Kim, C., 2014. Corporate social responsibilities, consumer trust and corporate reputation: South Korean consumers' perspectives. Journal of Business Research, 67(3), pp. 295-302.

Ponzi, L.J., Fombrun, C.J. and Gardberg, N.A., 2011. RepTrak ${ }^{\mathrm{TM}}$ pulse: Conceptualizing and validating a short-form measure of corporate reputation. Corporate Reputation Review, 14(1), pp. 15-35.

Pruzan, P., 2001. Corporate reputation: Image and identity. Corporate Reputation Review, [e-journal] 4(1), pp. 50-64. http://dx.doi.org/10.1057/palgrave.crr.1540132.

Ragas, M.W. and Roberts, M.S., 2009. Communicating corporate social responsibility and brand sincerity: A case study of Chipotle Mexican Grill's 'food with integrity' program. International Journal of Strategic Communication, 3(4), pp. 264-280.

Reichheld, F.F., 1996. The Loyalty Effect: The Hidden Force Behind Growth, Profits and Lasting Value. Boston: Harvard Business School Press.

Reputation Institute, 2013. Reputation Institute. [online] Available at: <www.reputationinstitute.com> [Accessed 14 February 2019].

Riera, M. and Iborra, M., 2017. Corporate social irresponsibility: Review and conceptual boundaries. European Journal of Management and Business Economics, [e-journal] 26(2), pp. 146-162. http://dx.doi.org/10.1108/EJMBE-07-2017-009.

Rindova, V.P., Williamson, I.O. and Petkova, A.P., 2010. Reputation as an intangible asset: Reflections on theory and methods in two empirical studies of business school reputations. Journal of Management, 36(3), pp. 610-619.

Roberts, P.W. and Dowling, G.R., 2002. Corporate reputation and sustained superior financial performance. Strategic Management Journal, 23(12), pp. 1077-1093.

Sen, S. and Bhattacharya, C.B., 2001. Does doing good always lead to doing better? Consumer reactions to corporate social responsibility. Journal of Marketing Research, 38(2), pp. 225-243.

Sergeant, A. and Frenkel, S., 2000. When do customer contact employees satisfy customers? Journal of Service Research, 3(1), pp. 18-34.

Shim, K. and Kim, J.-N., 2017. The impacts of ethical philosophy on corporate hypocrisy perception and communication intentions toward CSR. International Journal of Business Communication, [e-journal] First Published December 27, 2017. https://doi.org/10.1177/2329488417747597 
Stanaland, A.J.S., Lwin, M.A. and Murphy, P.E., 2011. Consumer perceptions of the antecedents and consequences of corporate social responsibility. Journal of Business Ethics, 102(1), pp. 47-55.

Van Riel, C.B.M., 1997. Research in corporate communication an overview of an emerging field. Management Communication Quarterly, 11(2), pp. 288-309.

Walker, K., 2010. A systematic review of the corporate reputation literature: Definition, measurement, and theory. Corporate Reputation Review, 12(4), pp. 357-387.

Wartick, S.L., 2002. Measuring corporate reputation. Definition and data. Business \& Society, 41(4), pp. 371-392.

Wei, Y.K., 2002. Corporate image as collect ethos: A poststructuralist approach. Corporate Communications, 7(4), pp. 269-276.

Werder, K., 2008. The effect of doing good: An experimental analysis of the influence of corporate social responsibility initiatives on beliefs, attitudes, and behavioral intention. International Journal of Strategic Communication, 2(2), pp. 115-135.

Whetten, D.A. and Mackey, A., 2002. A social actor conception of organizational identity and its implications for the study of organizational reputation. Business \& Society, 41(4), pp. 393-414.

Williams, R. and Barrett, J., 2000. Corporate philanthropy, criminal activity, and firm reputation: Is there a link? Journal of Business Ethics, 26(4), pp. 341-350.

Winkleman, M., 1999. The right stuff: Survey on corporate reputation. Chief Executive (U.S.), 143(April), pp. 80-81.

Windsor, D., 2013. Corporate social responsibility and irresponsibility: A positive theory approach. Journal of Business Research, 66(10), pp. 1937-1944.

Yoon, Y., Gürhan-Canli, Z. and Schwarz, N., 2006. The effect of corporate social responsibility (CSR) activities on companies with bad reputations. Journal of Consumer Psychology, 16(4), pp. 377-390. 